\title{
Podejście governance w polityce publicznej jako inspiracja dla uczenia się współdziałania dorosłych. Przykład gdańskiej polityki migracyjnej
}

\author{
The idea of governance in public policy as an inspiration \\ for adults to learn cooperation. \\ The example of Gdańsk migration policy
}

\begin{abstract}
Streszczenie. Analiza dokumentów dotyczących polskiej polityki migracyjnej, jak i literatury przedmiotu, skłania do sformułowania tezy, że polityka migracyjna podlega odmiennym prawom rozwojowym niż inne polityki publiczne w Polsce. W związku z nikłym reprezentowaniem idei współrządzenia w polityce migracyjnej uznać można, że nie ewoluuje ona w kierunku nowoczesnych koncepcji prowadzenia polityk publicznych, ale tkwi w modelu regulacyjnym lub korporacyjnym. Jako jedna z najtrudniejszych polityk sektorowych, rodząca liczne konflikty i niepokoje społeczne, powinna w większym stopniu polegać na współrządzeniu i współdecydowaniu obywateli. Zastosowanie koncepcji governance w tworzeniu i implementacji polityki migracyjnej ma także duży potencjał edukacyjny. Jako przykład nowocześnie konstruowanej polityki migracyjnej na poziomie lokalnym przedstawiony został w artykule gdański model integracji imigrantów.
\end{abstract}

Słowa kluczowe: polityka publiczna, polityka migracyjna, governance

Summary. Migration policy is a one of the public policies. In Poland, migration policy is very traditional. It does not change, like other public policies. It does not present idea of governance and community participation. This is one of the most difficult policies and should be based on modern social management. If society have the opportunity to decide about local migration policy, will be much less conflicts with immigrants. The governance concept has an educational potential. A good example, how to educate the local community for migrations, is a model of migrant integration, which is implemented in Gdańsk.

Key words: public policy, migration policy, governance 


\section{Wstęp}

Dla edukacji człowieka dorosłego niezwykle istotny jest jej społeczny kontekst, ze szczególnym uwzględnieniem doświadczeń nabywanych w procesie partycypacji społecznej i obywatelskiej. Zwolennicy perspektywy społeczno-kulturowej upatrują $\mathrm{w}$ tej właśnie przestrzeni nowych możliwości edukacyjnych, które mają miejsce głównie w interakcjach wypełniających wszystkie rodzaje praktyk społecznych, w jakich ludzie dorośli uczestniczą (Malewski 2013, s. 31). Jedną z takich praktyk może być proces partycypacyjnego tworzenia polityk publicznych, zgodnie z ideą nowoczesnego podejścia w kreowaniu tej przestrzeni, jaką jest governance. Idea współrządzenia to podmiotowe traktowanie społeczności lokalnych i ich rzeczywisty udział w podejmowaniu decyzji dotyczących własnego środowiska życia. Dobrym przykładem takiego procesu może być jedna z ważniejszych współcześnie polityk publicznych, jaką jest polityka migracyjna. Podejmowanie decyzji politycznych w oparciu o zasady partycypacji, stanowić może istotny obszar doświadczeń edukacyjnych, kształtujących pozytywnie relacje pomiędzy migrantami i członkami społeczności ich przyjmujących. To swoista edukacja międzykulturowa w działaniu, która mogłaby wesprzeć i kreować rzeczywiste, a nie deklarowane, postawy tolerancji i otwartości. Governance może wspierać kształtowanie nie tylko kompetencji adaptacyjnych, ale i twórczych, poprawiających zdolność radzenia sobie z różnymi zmianami zachodzącymi we współczesnym świecie, w tym procesami migracyjnymi. Upowszechnianie każdej innowacji zależy bowiem od: „mobilności ludzi i idei, elastyczności, tworzenia wokół nowych idei zespołów, mobilizacji zasobów, kultury współdziałania, gotowości eksperymentowania, zaufania" (Przyborowska 2014, s. 91). To fundamentalne czynniki rozwoju każdego społeczeństwa.

Współcześnie polityki publiczne podlegają znaczącym przeobrażeniom modelowym. W krajach Europy Zachodniej widzimy zaawansowany proces przechodzenia „od rządu do zarządzania i współrządzenia” - koncepcja governance. Rządy wypracowują nowe metody rozwiązywania problemów społecznych, głównie w systemie partnerstw, przez co wytwarza się większa niż kiedyś płaszczyzna interesu zbiorowego (Zybała 2015, s. 32). Partycypacyjne zarządzania publiczne jest określane mianem współrządzenia, a podstawowe założenia takiego modelu to interakcja z interesariuszami (obywatelami, organizacjami pozarządowymi, przedsiębiorcami), zastosowanie zasady partycypacji i konsultacji, jawność, przejrzystość, odpowiedzialność, zrównoważony rozwój (Szumowski 2014, s. 91-95). Governance, jako nowy model zarządzania publicznego z udziałem społeczeństwa, staje się także ważną 
płaszczyzną edukacyjną. Poprzez uczestniczenie w społecznej przestrzeni, wszystkie podmioty polityczne są „zmuszane” do samorefleksji i kreatywności (Hausner 2007, s. 55). Może być to określane mianem uczenia się w działaniu, uczenia się poprzez uczestnictwo, partycypacyjnego uczenia się.

W wielu opracowaniach rządowych pojawia się deklaracja, iż w Polsce należy budować nowoczesną politykę publiczną we wszystkich sektorach. Nowoczesną, czyli wedle modelowych przemian w koncepcjach tworzenia polityk publicznych, opartą na koncepcji governance. Jak idea governance reprezentowana jest w polskiej polityce publicznej na poziomie rządowym lub samorządowym oraz jakie możliwości edukacyjne może mieć partycypacyjne tworzenie polityk publicznych na przykładzie polityki migracyjnej? To pytania, na które podejmę próbę odpowiedzi w niniejszym artykule, na podstawie analizy literatury przedmiotu, materiałów o charakterze raportowym oraz dokumentów rządowych i samorządowych dotyczących polskiej polityki migracyjnej. Polityka migracyjna tworzona zgodnie z koncepcją governance wydaje się obecnie niemal koniecznością. Może stanowić bowiem doskonałą przestrzeń uczenia się obywatelskości i tolerancji wobec odmienności.

\section{Governance jako nowoczesna koncepcja tworzenia polityki publicznej}

Słowo polityka najczęściej kojarzone jest z pojęciem władzy i zarzadzania. Uosabia działanie polegające na kierowaniu zachowaniem innych ludzi z chęci realizacji określonych celów. Istnieje wiele rodzajów działań o charakterze polityk, ale w kontekście działań służących realizacji interesu publicznego mówimy o public policy, czyli polityce publicznej. W najszerszym ujęciu polityka publiczna oznacza zracjonalizowane działania i programy publiczne (lub ich brak), które oparte są na zgromadzonej i względnie zobiektywizowanej wiedzy i usystematyzowanym procesie projektowania i wykonywania tych działań (Zybała 2012, s. 24). To nadawanie porządku zadaniom publicznym, od ich projektowania, poprzez realizację, aż po ocenę rezultatów. Inna definicja uznaje, iż przez politykę publiczną należy rozumieć zamierzony i celowy proces realizacji ogólnych założeń w poszczególnych obszarach życia obywateli, które mogą wynikać $z$ „wizji” rządzących na poziomie zarówno centralnym, jak i lokalnym, a których celem jest zaspokajanie potrzeb społecznych.

Współcześnie polityka publiczna zawiera w sobie trzy główne obszary działań - wybory programowe (programy, strategie, projekty) wykony- 
wanie programów publicznych (działania realizowane przez administrację i jej współpracowników np. sektor pozarządowy) oraz rezultaty działań publicznych i ich wpływ na życie obywateli (nie powinny być utożsamiane z produktami, które mają ograniczony charakter) (Zybała 2013, s. 42-43). Dwa pierwsze obszary zwracają uwagę na to, iż współczesna polityka publiczna nie jest uzależniona tylko od jednego podmiotu np. państwa, ale od wielu instytucji zaangażowanych $w$ proces jej programowania i realizacji. Jest procesem uporząadkowanych i ukierunkowanych działań różnych podmiotów, których celem jest dobro obywateli. W nowocześnie uprawianych politykach publicznych poszerza się przestrzeń dla partycypacyjnych mechanizmów ich uzgadniania. Od lat siedemdziesiątych widać w krajach europejskich swoiste przejście od państwa jako instytucji interwencjonistycznej, do państwa jako instytucji regulacyjnej (prywatyzacja, liberalizacja i deregulacja w politykach publicznych) (Zybała 2013, s. 27).

Model zarzadzania publicznego przyjęty w danym kraju jest obecnie tym aspektem, który bardzo silnie wpływa na formułowanie i wykonywanie interesujących nas polityk. Andrzej Zybała, powołując się na ujęcie Michaela P. Howletta, charakteryzuje cztery najczęściej spotykane modele zarzadzania publicznego. Jeden opiera się na zarzadzaniu przez legislację, gdzie główny nacisk działań publicznych skierowany jest na konstruowanie regulacji prawnych, dzięki którym tworzona jest struktura porządku w relacjach publicznych. Kolejny model określany jest jako zarządzanie przez korporacje, którymi są grupy reprezentujące interesy społeczne (np. związki zawodowe). Inny model to zarządzanie poprzez rynek, charakteryzujące się wykorzystywaniem w zarządzaniu publicznym reguł konkurencji w obszarze usług społecznych - New Public Management. Ostatni charakteryzowany model to zarządzanie poprzez sieci, gdzie kluczowym elementem są relacje pomiędzy różnymi grupami i ich współpraca w realizacji zadań publicznych - public governance, good governance lub governance (Zybała 2013, s. 33-34). To poniekąd odpowiedź na krytykę nowego zarządzania publicznego, zakładająca prowadzenie polityki publicznej w oparciu o sieciowe struktury i nawiązywanie współpracy z różnorodnymi aktorami życia publicznego. Cechy good governance to:

- stwarzanie warunków, głównie instytucjonalnych, dla efektywnej realizacji celów publicznych;

- łączenie instrumentów ekonomicznych i administracyjnych w polityce publicznej;

- decentralizacja uprawnień decyzyjnych w sektorze publicznym; 
- wykorzystywanie partnerstwa publiczno-prywatnego i instytucji pozarządowych do realizacji celów społecznych i dostarczania dóbr publicznych;

- stosowanie różnych kanałów komunikowania się społeczeństwa z sektorem publicznym;

- $\quad$ społeczne monitorowanie działań rządu (państwa) i stwarzanie instytucjonalnych warunków do egzekwowania podjętych przez rząd zobowiązań (Wilkin 2010, s. 32).

Myślenie w kategoriach governance stwarza nowe ramy rozwoju demokracji i społeczeństwa obywatelskiego. Odchodzi się od traktowania jednostek tylko jako wyborców, wolontariuszy i konsumentów. W zamian powierza się im możliwość wpływania na kształt rozwiązań problemów, które ich dotyczą. Traktuje się ich jak współdecydentów i współkreatorów dobra społecznego. Stanowi to być może początek odchodzenia od demokracji wyborczej, na rzecz pogłębiania obywatelskiego, horyzontalnego, pluralistycznego i produktywnego wymiaru polityki (Izdebski 2007, s. 15). Obywatele mają prawo czynnie uczestniczyć w życiu publicznym, a także kontrolować władzę na bieżąco, a nie tylko w momencie wyborów. Jest to działanie szczególnie przydatne w zarządzaniu na poziomie środowiska lokalnego. Zgodnie $\mathrm{z}$ koncepcją governance $\mathrm{w}$ kształtowaniu polityki publicznej eksponowane jest znaczenie kapitału społecznego, społeczeństwa obywatelskiego oraz wysoki poziom partycypacji społecznej, szczególnie istotny w planowaniu i wdrażaniu przyjętych rozwiązań (Banachowicz 2007). Na określenie administracji publicznej z punktu widzenia społeczeństwa obywatelskiego coraz częściej używa się terminu public governance.

Idea współrządzenia, stała się tym bardziej nośna, bo upatruje się w niej remedium na kryzys partycypacji obywatelskiej w wielu krajach, by poprzez umożliwienie obywatelom współdecydowania o kształcie sektora publicznego, zwiększyć ich zaangażowanie w sferze publicznej. Celem tych działań jest zarówno zwiększenie udziału obywateli w procesach decyzyjnych, co wpływać może na ich doskonalenie; jak i poprawa jakości usług publicznych z jednoczesnym zwiększeniem wsparcia i przychylności obywateli do proponowanych zmian (idea tworzenia i wdrażania mechanizmu świadczenia dobrej jakości usług społecznych, realizowanych przy maksymalnym wykorzystaniu lokalnych zasobów).

W ostatnich dwóch dekadach widać znaczący wzrost zainteresowania koncepcją współrządzenia. Może to wynikać z dyskusji nad rolą państwa w warunkach globalizacji, nad efektywnością sektora publicznego oraz wzmacnianiem demokracji. Jest to podejście zalecane wszystkim krajom 
członkowskim przez Komisję Europejską, która wyróżnia następujące kryteria dobrego rządzenia:

- otwartość (openness), jawność i dobry dostęp do informacji publicznej oraz procedur administracyjnych, transparentność instytucji państwowych, wolność od korupcji;

- partycypacja (participation), współuczestnictwo społeczeństwa w procesie rządzenia na każdym jego poziomie (multilevel governance) i każdym etapie funkcjonowania polityki publicznej, wspieranie rozwoju społeczeństwa obywatelskiego;

- rozliczalność (accountability), polityczna odpowiedzialność za podejmowane decyzje, jak również odpowiedzialność za zaniechanie ich podejmowania czy też implementowania, klarowny podział obowiązków i specyfikacja celów interwencji, co wiąże się z możliwością dokonywania ewaluacji poprzez zewnętrzne organizacje, a także możliwość zidentyfikowania podmiotu odpowiedzialnego za błędne decyzje oraz pociągnięcia go do tej odpowiedzialności;

- skuteczność (effectiveness), zakres osiągania założonych rezultatów, czyli potencjał państwa (state capacity) do wykonania stosownej interwencji;

- spójność (coherence), trwałość instytucji i kumulatywny rozwój wiedzy o zarządzaniu nimi, dążenie do wypracowania i implementacji sprawdzonych procedur, promowanie organizacji uczących się, a także zgodność celów interwencji niższego szczebla z celami interwencji wyższego szczebla (Górniak i inni 2010, s. 8).

Governance, jako proces zarządzania publicznego z udziałem społeczeństwa staje się także bardzo korzystną przestrzenią edukacyjną. Poprzez uczestniczenie w społecznej przestrzeni, wszystkie podmioty polityczne są „zmuszane” do samorefleksji i kreatywności (Hausner 2007, s. 55). Brytyjski Institute for Government wskazuje w swoich publikacjach, że współkształtowanie polityki publicznej ma refleksyjny i uczący charakter. Dotyczy to zarówno fazy projektowania jak i budowania systemu wdrażania, implementacji oraz ewaluacji (Skrzypczak 2016, s. 92-95). Koncepcja współzarządzania jest bowiem oparta na sieciowaniu, zarządzaniu wielopoziomowym, uczeniu kompromisu, dialogu oraz partycypacji publicznej. Edukacyjny wymiar koncepcji governance był impulsem do myślenia o nowej dziedzinie pedagogiki, jaką może się stać pedagogika publiczna uprawiana jako refleksja teoretyczna i praktyczna, stawiająca w centrum uwagi „mechanizmy wychowawczego / edukacyjnego kształtowania i rozwoju społeczeństwa przez oddziaływanie systemowe / instytucjonalne" (Skrzypczak 2016, s. 30). By 
jednak taka sytuacja mogła mieć miejsce, do współrządzenia musi zostać zaproszona społeczność. Szczególnie praca ze społecznościami lokalnymi staje się ważnym ogniwem tworzenia i realizacji programów i sektorowych polityk publicznych.

Przedmiotem obywatelskich oddziaływań mogą być zarówno procesy ustawo- i uchwałodawcze, jak i wykonawcze. Może się to odbywać z wykorzystaniem różnych form demokracji partycypacyjnej (np. konsultacje społeczne, referenda) i deliberatywnej (np. sondaż deliberatywny, obywatelskie jury), a także na drodze lobbowania, protestu, nieposłuszeństwa obywatelskiego czy rzecznictwa. Działania tego rodzaju mogą być podejmowane na różnych szczeblach - od centralnego (rząd i parlament), przez regionalny, po szczebel powiatu i gminy / miasta. Angażowanie obywateli w procesy decyzyjne to w dużej mierze działania inicjowane i kontrolowane przez władze publiczne, w toku wypełniania ich statutowych zadań administracyjnych lub zarządczych.

By jednak taka sytuacja mogła mieć miejsce, do współrządzenia musi zostać zaproszona społeczność. Powszechnie uważa się, że podmioty administracyjne zachęcają społeczeństwo do dialogu, ale obserwując wiele takich sytuacji dochodzę do przekonania, że są to działania bardzo nieudolne lub nawet pozorowane. Polacy już dawno utracili poczucie samostanowienia i przerzucają odpowiedzialność za własny los z siebie na państwo (Giza-Poleszczuk 2007, s. 72). Rekonstrukcja paradygmatu współzarządzania wymaga czasu i wielu zabiegów zarówno na szczeblu centralnym, jak i lokalnym, by polityki mogły stać się instrumentami świadomego i celowościowego kształtowania postaw społeczeństwa.

\section{Obecność koncepcji governance w państwowej i samorządowej polityce migracyjnej}

Z analizy polskich dokumentów strategicznych dotyczących polityki migracyjnej, można wnioskować o znikomej obecności idei governance. W latach dziewięćdziesiątych w Polsce, jak czytamy w dokumencie Polityka migracyjna Polski - stan obecny i postulowane działania, „wobec niewielkiego zainteresowania społeczeństwa problematyką migracji (również organizacje pozarządowe nie były tak liczne i aktywne jak obecnie), rozwiązania i decyzje proponowane przez właściwe instytucje państwowe były podejmowane i realizowane bez publicznych debat i dyskusji politycznych" (Polityka migracyjna..., s. 6). Dokument ten zawiera wiele wskazań dotyczących kierunków 
polskiej polityki migracyjnej, nie zawiera jednak żadnego zapisu o partycypacyjnym jej kształtowaniu ani przez polskie społeczeństwo, ani przez diaspory imigrantów.

Pośród rekomendacji zawartych w ekspertyzie podsumowującej doświadczenia teoretyczne i empiryczne nad społecznym i ekonomicznym wymiarem integracji (moduł III -Integracja cudzoziemców w Polsce), projekt zrealizowanego w ramach Europejskiego Funduszu Społecznego, Sektorowy Program Operacyjny Rozwój zasobów ludzkich (działanie 1.1 a), pt. Polityka migracyjna jako instrument promocji zatrudnienia i ograniczania bezrobocia odnajdujemy postulat, by struktura i działania w ramach polityki migracyjnej miały charakter zdecentralizowany. Urzędy centralne powinny posiadać funkcję decyzyjno-nadzorczą, a struktury samorządowe - konsultacyjno-wykonawczą, z realnym wpływem na podejmowane decyzje. Do współpracy powinien być zaproszony sektor pozarządowy oraz przedstawiciele społeczności imigranckich.

Dokumentem samorządowym, który warto szerzej omówić, jest gdański Model Integracji Imigrantów (w skrócie MII), stworzony i realizowany w mojej opinii z wykorzystaniem koncepcji governance. Gdańsk jest pierwszym miastem w Polsce, które stworzyło i przyjęło uchwałą Rady Miasta dokument dotyczący integracji imigrantów. Określa on obszary i kierunki działań zmierzające do prowadzenia skutecznej i efektywnej polityki Miasta Gdańska dotyczącej integracji imigrantów oraz zawiera wytyczne i rekomendacje w zakresie jej realizacji. Model uzyskał uznanie i wsparcie polskiego Biura Wysokiego Komisarza Narodów Zjednoczonych ds. Uchodźców (UNHCR). Pierwotnym założeniem było opracowanie i wdrożenie konkretnych rozwiązań ukierunkowanych na mieszkających już i pracujących w Gdańsku imigrantów. Chodziło o wypracowanie takich rozwiązań, by ich potrzeby i problemy były lepiej adresowane i rozwiązywane. Nie wyklucza to jednak potrzeby prac i wdrażania działań w zakresie przyjmowania i wspierania nowych imigrantów przybywających do Gdańska, co umożliwi stawianie czoła wyzwaniom związanym z przewidywanym wzrostem migracji w ciągu najbliższych lat.

MII ukazuje główne obszary i kierunki działań zmierzających do prowadzenia skutecznej i efektywnej polityki integracyjnej w samorządzie lokalnym, w dłuższym wymiarze czasowym. Celem głównym Modelu Integracji Imigrantów jest rozwój systemu zarządzania migracjami w instytucjach publicznych i społecznych w Gdańsku oraz wzmocnienie integracji imigrantów i imigrantek w takich obszarach jak: edukacja, kultura, pomoc społeczna, mieszkalnictwo, przeciwdziałanie przemocy i dyskryminacji, społeczno- 
ści lokalne, zatrudnienie i ochrona zdrowia. We wszystkich wymienionych priorytetach zostały zaprezentowane cele, zadania oraz działania szczegółowe. Podmioty uczestniczące w procesie integracji to: Miejski Ośrodek Pomocy Rodzinie, Urząd Pracy, Urząd Skarbowy, Urząd Miasta, policja, instytucje edukacyjne (żłobek, przedszkole, szkoła, uczelnia), szkoły językowe, zakłady opieki zdrowotnej, pracodawcy, wolontariusze i organizacje pozarządowe. Zespół ds. wdrożenia MII ma składać się z czterech głównych podmiotów:

- Komitetu Sterującego, składającego się z przedstawicieli kadry zarządzającej najważniejszych i kluczowych dla wdrażania MII instytucji i organizacji w Gdańsku;

- Grupy Zarządzającej, w której skład powinni wejść liderzy ośmiu obszarów tematycznych, na których wdrażany będzie MII. Możliwe jest poszerzenie składu tego gremium o ekspertów oraz liderów innych obszarów tematycznych, nieopisanych szczegółowo w MII, np. sportu.

- Forum Integracji i Migracji, w którego składzie znajdzie się możliwie jak najwięcej instytucji, organizacji i osób gotowych rozwijać i wdrażać działania w zakresie integracji i migracji w Gdańsku. Punktem wyjścia do stworzenia tego podmiotu jest potrzeba tworzenia przestrzeni do wymiany wiedzy i doświadczeń w zakresie integracji imigrantów i wspierania rozwoju kompetencji międzykulturowych gdańskiej społeczności;

- Rady Imigrantów złożonej z przedstawicieli środowisk imigranckich zamieszkujących w Gdańsku Istnieje bowiem potrzeba rozbudzenia zaangażowania tego środowiska.

$\mathrm{Z}$ perspektywy budowania lokalnych polityk migracyjnych $\mathrm{w}$ oparciu o koncepcję governance, najbardziej interesująca jest część dotycząca konsultacji społecznych. Okazuje się, że były one kilkumiesięczne i realizowane na różne sposoby. Odbywały się konferencje i seminaria, warsztaty i debaty z mieszkańcami, spotkania konsultacyjne z osobami znaczącymi w środowisku Gdańska, wizyty studyjne. Odbywały się także konsultacje on-line. Ważnym i ciekawym elementem konsultacji była wizyta mentoringowa EUROCITIES (zrzeszenie największych miast europejskich) w zakresie miasta integrującego. Zagadnieniem głównym tej wizyty była kwestia komunikacji społecznej i budowania kontaktu z mieszkańcami i opinią publiczną w zakresie migracji i integracji. EUROCITIES wybrało Barcelonę i Gandawę oraz MigrationWork z Anglii do realizacji wsparcia mentoringowego i wizyty w Gdańsku (Fedas, Siciarek, Olech 2016, s. 14-15). 
Obok konsultacji społecznych na poziomie tworzenia dokumentu, ukazuje on wiele możliwości włączania podmiotów pozarządowych i społecznych w jego implementację (Forum Integracji i Migracji, Rada Migrantów). Otwiera także przestrzeń do debaty publicznej na temat migracji, tworzy okazję do nabywania kompetencji międzykulturowych oraz uczenia się przez społeczność Gdańska tolerancji w stosunku do inności. Całość podjętych działań stanowi doskonały przykład oparcia się na koncepcji gonernance $\mathrm{w}$ tworzeniu i realizacji lokalnej polityki migracyjnej.

Gdańsk posiada także duży zasób dobrych praktyk w obszarze integracji imigrantów. Można przywołać doświadczenia Europejskiego Centrum Solidarności", gdzie już w 2014 roku realizowano Program edukacji i praktyki obywatelskiej dla imigrantów i imigrantek mieszkających w Trójmieście. Program wychodził na przeciw aktywizacji imigrantów wokół sfery publicznej, grupy niedostrzeganej przez państwo, lokalne samorządy oraz niektóre programy społeczne i obywatelskie, często pozbawianej wsparcia i współudziału, a także współdecydowania w kwestiach, które ich dotyczą. Kolejne inicjatywy to np.: program wolontariatu w organizacjach / instytucjach kultury jako narzędzie integracji migrantów, Klub Obcokrajowca w bibliotece Europejskiego Centrum Solidarności czy konferencja Kodeks dobrych praktyk dla przedsiębiorców chcących zatrudnić cudzoziemców - jak teorię przekuć w praktykę, zorganizowana dzięki współpracy Pracodawców Pomorza, Międzynarodowej Organizacji ds. Migracji, Powiatowego Urzędu Pracy w Gdańsku oraz Work Service S.A., przy wsparciu Pomorskiego Urzędu Wojewódzkiego w Gdańsku.

\section{Podsumowanie}

Analiza rządowych dokumentów dotyczących polityki migracyjnej ukazuje nikłe reprezentowanie idei współrządzenia w tym sektorze. Polityka migracyjna nie ewoluuje w kierunku nowoczesnych koncepcji prowadzenia polityk publicznych, ale tkwi w Polsce w modelu regulacyjnym lub korporacyjnym. Wydaje się to dość niepokojące, gdyż jest to jedna z najtrudniejszych polityk sektorowych i w celu uniknięcia sytuacji konfliktowych, wszelkie decyzje władz powinny być poparte szerokimi konsultacjami społecznymi. Dotyczy to zarówno społeczności przyjmujących, jak i społeczności imigranckich.

* http://www.ecs.gda.pl/imigranci, dostęp w dniu 10.07.2017. 
Zarządzanie migracjami z poziomu centrum jest łatwiejsze i szybsze, ale niestety mniej skuteczne. Współcześnie obserwowana polityka migracyjna Unii Europejskiej prowadzona jest często z pominięciem nawet poziomu rządowego (nie mówiąc już o poziomie lokalnym), co może być źródłem niepotrzebnych konfliktów, które i tak migracje wywołują, zwłaszcza jeśli występują w dużej skali. Dla rozwiazywania licznych negatywnych zjawisk społecznych związanych $\mathrm{w}$ imigrantami potrzebna jest partycypacja poziomu lokalnego $\mathrm{w}$ tworzeniu państwowej polityki migracyjnej (multi-level governance). Poziom lokalny, rozumiany jako poziom miasta i gminy, odgrywa w tym procesie istotniejszą rolę niż poziomy wyższe (regionalny, państwowy), gdyż adaptacja imigrantów przebiega właśnie w społecznościach poszczególnych miast i gmin, a odpowiadają za nią samorządy lokalne. W przypadku problemów z integracją, to one ponoszą główny ciężar ich rozwiązania. Większość imigrantów osiedla się w miastach, a jak wynika z badań przeprowadzonych przez Krisa Vancluysena, Maarten Van Craen i Johana Ackaerta imigranci budują poczucie przynależności ze społecznością lokalną, miastem, dzielnicą i sąsiedztwem, co nie zawsze przekłada się na poczucie związku z państwem przyjmującym, w którym mieszkają (Matusz-Protasiewicz 2014, s. 12).

W Polsce samorządy lokalne mają niewielkie doświadczenie w budowaniu własnej polityki migracyjnej. Są w dużej mierze zdane na decyzje szczebla rządowego, których podejmowanie nie odbywa się na drodze zarządzania wielopoziomowego. Na tym tle znacząco wyróżnia się samodzielna inicjatywa Gdańska. Stworzony tam Model Integracji Imigrantów jest pierwszym kompleksowym dokumentem strategicznym na poziomie lokalnym, który proponuje konkretne działania wspierające imigrantów mieszkających na terenie miasta. Dokument ten odpowiada także nowoczesnej koncepcji tworzenia polityk publicznych, jaką jest governance. Jego realizacja zapewne zmniejszy ilość i natężenie niepokojów społecznych związanych ze zjawiskiem migracji w społeczności miasta. Każda nowocześnie tworzona polityka, niezależnie od dziedziny, uruchamia bowiem procesy strategiczne, procesy operacyjne i procesy uczenia się. Procesy strategiczne odnoszą się do definiowania głównych celów danej polityki i alokacji niezbędnych dla ich realizacji zasobów. Procesy operacyjne to wdrażanie zaplanowanych działań, a procesy uczenia się to stopniowa adaptacja otoczenia procesu, do zmian, które poprzez procesy strategiczne i operacyjne zostały uruchomione. A zjawisko migracji, ujęte $w$ dobrze zaprojektowaną polityką publiczną, może stać się nową przestrzenią edukacyjną współczesnego człowieka. Włączanie w działania społeczne staje się wspomaganiem jednostek w nabywaniu po- 
staw, umiejętności i wiedzy niezbędnej dla ich demokratycznej partycypacji w rozwiązywaniu nie tylko lokalnych, ale i ponadlokalnych problemów, co dla współczesnej polityki publicznej może być największym wyzwaniem.

\section{Bibliografia}

Banachowicz B. (2007), Public governance - nowe podejście do zarządzania rozwojem lokalnym, [w]: Strahl D. (red.), Gospodarka lokalna i regionalna w teorii i praktyce, „Prace Naukowe AE im. Oskara Langego we Wrocławiu”, 1161, Wyd. AE im. O. Langego, Wrocław, s. 613-622.

Ekspertyza podsumowująca doświadczenia teoretyczne i empiryczne nad społecznym i ekonomicznym wymiarem integracji (moduł III - Integracja cudzoziemców w Polsce), Projekt zrealizowanego w ramach Europejskiego Funduszu Społecznego, Sektorowy Program Operacyjny Rozwój zasobów ludzkich (działanie 1.1 a), pt. Polityka migracyjna jako instrument promocji zatrudnienia i ograniczania bezrobocia, Ośrodek Badań nad Migracjami, Wydział Nauk Ekonomicznych Uniwersytet Warszawski, 2007.

Fedas A., Siciarek M., Olech P. (red.) (2016), Model integracji imigrantów, Wyd. Urząd Miejski w Gdańsku, Wydział Rozwoju Społecznego, Gdańsk.

Giza-Poleszczuk A. (2007), Dobre rządzenie i debata publiczna, „Zarządzanie Publiczne", 1, s. 61-79.

Hausner J. (2007), Polityka a polityka publiczna, „Zarządzanie Publiczne”, 1, s. 43-60 .

Izdebski H. (2007), Od administracji publicznej do public governance, „Zarządzanie Publiczne", 1, s. 7-20.

Malewski M. (2013), „Dorostość” - kłopotliwa kategoria andragogiki, „Teraźniejszość - Człowiek - Edukacja", 3(63), s. 23-40.

Matusz-Protasiewicz P. (2014), Wielopoziomowe zarządzanie migracjami. Rola Europejskiego Funduszu na rzecz Integracji Obywateli Państw Trzecich $w$ kształtowaniu polityki integracyjnej w Polsce, Wyd. Prawnicza i Ekonomiczna Biblioteka Cyfrowa, Wrocław.

Polityka migracyjna Polski - stan obecny i postulowane działania, Dokument przyjęty przez Radę Ministrów w dniu 31 lipca 2012 roku, opracowany przez Zespół do Spraw Migracji, red. Ministerstwo Spraw Wewnętrznych, Departament Polityki Migracyjnej.

Przyborowska B. (2014), Fundamenty innowacyjnego społeczeństwa, „Rocznik Andragogiczny", 21, s. 89-99.

Skrzypczak B. (2016), Pomiędzy społecznym a publicznym - nowa przestrzeń edukacji i refleksji, „Pedagogika Społeczna”, 3, s. 9-36. 
Szumowski W. (2014), Zarządzanie publiczne - próba systematyzacji koncepcji, „Nauki o Zarzadzaniu. Menagement Science”, 4, s. 86-98.

Wilkin J. (2010), Słabość państwa w jego relacji do gospodarki i słabość ekonomicznej teorii państwa, „Zarządzanie Publiczne”, 1(11), s. 25-35.

Zybała A. (2012), Polityki publiczne. Doświadczenia w tworzeniu i wykonywaniu programów publicznych $w$ Polsce $i w$ innych krajach. Jak działa państwo, gdy zamierza/chce/musi rozwiqzać zbiorowe problemy swoich obywateli?, Wyd. Krajowej Szkoły Administracji Publicznej, Warszawa.

Zybała A. (2013), Państwo i społeczeństwo w działaniu. Polityki publiczne wobec potrzeb modernizacji państwa i społeczeństwa, Wyd. DIFIN, Warszawa.

Zybała A. (2015), Polityka publiczna wobec teorii i jej praktyki w Polsce, „Wrocławskie Studia Politologiczne", 18, s. 28-43.

\section{Netografia}

Górniak J., Worek B., Antosz P., Drożdżak Z., Orkisz W. (2010), Ewaluacja oparta na badaniu użyteczności - analiza w kontekście realizacji zasady good governance $\mathrm{w}$ wybranych programach operacyjnych. Projekt zrealizowany w ramach III konkursu dotacji Fundusze europejskie na poziomie NSS przez zespół Centrum Ewaluacji i Analizy Polityk Publicznych UJ, Warszawa, http://www.portal.uj.edu.pl/ documents/4628317/5fd8f097-8ce8-4ad7-af64-6c386fa6a51e, dostęp w dniu 15.03.2017. 